\title{
PNPRS LECTURE SERIES 2019
}

\author{
Co-host: College of Graduate Studies and Teacher Education Research \\ Philippine Normal University
}

\section{Theme: Philosophy of Education at the Margins}

\author{
September 6, $2019 \quad 1-5 \mathrm{pm}$ \\ Main Auditorium, Philippine Normal University, Manila
}

\section{PR O GRA M}

I. Registration

II. Opening Programme

Doxology \& National Anthem - AVP

Opening Remarks Ronald Allan S. Mabunga, Ph.D. Dean-CGSTER

Jove Jim S. Aguas, Ph.D. Executive Governor, PNPRS

Introduction of PNPRS Officers -Juan Rafael G. Macaranas, Ph.D.

Chairman of the Board, PNPRS

Giving of Certificates of Appreciation

Acknowledgement of Participants

Picture Taking

Introduction of the Session

III. Lecture Proper

Introduction of the 1st Speaker

Lecture 1 - Marella Ada Mancenido-Bolanos, Ph.D.

Transformation of Teachers Students in a Community of Inquiry Introduction of the 2nd Speaker

Lecture 2 - Rodrigo D. Abenes, Ph.D.

Traces of Critical Pedagogy in Rizal's Philosophy of Education

Open Forum

Consultation (Teacher's Summit)

Closing Remarks - Inero Vancho Ph.D. CGSTER Program Cluster

Coordinator

In Memoria: Dr. Rolando M. Gripaldo

HATPNU HYMN LANP

Ernie M. Pamor

Master of Ceremony 